\title{
Joachim Du Bellay's Dream Language: The Songe as Allegory of Poetic Signification
}

HASSAN

MELEHY

Résumé : Dans cet article, l'auteur se propose d'interpréter le Songe de Joachim Du Bellay comme travail du rêve, au sens psychanalytique. Cette série de poèmes a souvent été critiquée pour son obscurité; mais c'est en fonction de cette obscurité qu'elle révèle son sens, qui porte sur le flux constant du sens des signes poétiques. La disposition des signes $d u$ Songe met l'accent sur la distance entre signifiant et signifié, notamment en ce qui concerne le signifiant «Rome »: la construction onirique de Rome accomplit la destruction de la Rome antique, pour que la nouvelle poésie française se forme. Comme texte de rêve dont les signes indiquent des sens inattendus, le Songe présente allégoriquement une théorie de la signification poétique, celle-ci impliquant l'allégorie, ou la capacité des signes de transformer leur propre sens.

\section{Questions of interpretation}

Since its first appearance in 1558, Joachim Du Bellay's Songe has elicited numerous reactions of puzzlement. The dreamlike imagery and associations of its fifteen sonnets have been termed "obscure" by more than one critic, although there has not been agreement as to whether such a qualification signals a weakness. ${ }^{1}$ While it has lately been recognized that $\mathrm{Du}$ Bellay's appending of the Songe ou Vision sur le mesme subject to the Antiquitez de Rome suggests that the author considered the two to be of similar importance, and the second sequence to be another treatment of the subject matter of the first, ${ }^{2}$ some of the most thorough critical texts on the Antiquitez still devote very little space to the Songe. ${ }^{3}$ The Songe has often if not always been accorded the status of allegory, and if it is held to be obscure, the obscurity is either cleared through decipherment or simply left aside. $^{4}$ 
Among the critics who have attempted decipherment, offering a fixed meaning to the elusive words, there is no agreement on what the "other story," so to speak, ${ }^{5}$ of this allegory is - an effect that Sharlene May Poliner attributes to the withholding of the key signifier: "Despite the specific mention of Rome in the collection's title, there is so much ambiguity created by the absent name that refuses inscription in the Songe that the images in the visions invite a seemingly endless number of interpretations." 6 By no means claiming to exhaust Du Bellay's sonnet sequence, Gilbert Gadoffre does a magisterial deciphering of the Songe as a Gallicanist allegory of pontifical Rome. ${ }^{7}$ Even Michael Riffaterre's characteristically thorough reading of Songe 7 through a complex series of intertextual signs ends up settling on a particular chain of signification for the poem's signifiers. ${ }^{8}$ Without the least intention of devaluing these and other attempts at tackling such a difficult text, I would like to suggest that the very condition of obscurity in which the signs of the poems find themselves constitutes an essential component of the meaning of the Songe, which, as I hope to show, involves the capacity of words to signify in multiple fashion.

I am in full agreement with Riffaterre that the purpose of the obscurity of the Songe is to reveal rather than to conceal. ${ }^{9}$ I hold, however, that this revealing is to be understood as the work of a dream, in accordance with Freud's description of this process, especially in The Interpretation of Dreams. As Jacques Lacan has observed in numerous places, Freud offers an elaborate theory of the associational relations among linguistic signs in his works on the unconscious. Du Bellay presents relations among signs that, as I intend to demonstrate, are associational in similar fashion, so that meaning comes to be seen as a matter of relations among signs rather than as grounded in the objects to which signs refer. The procedures of $\mathrm{Du}$ Bellay's allegory become more apparent when viewed in the perspective Freud provides, in which the potential of signs to produce meaning is greatly extended and transmutations in the relations between signifier and signified continually occur. In "L'instance de la lettre dans l'inconscient," Lacan points out that one of the great values of The Interpretation of Dreams is that it frees the dream-image from its relation to the object it ostensibly represents; it assimilates the signifying capacity of the dream-image to that of a letter, which may, in the nearly endless combinations that written language may place it, produce and traverse any number of meanings. ${ }^{10}$ Freud's work bears on the material texture of language and its troping properties, and hence may be seen as a theory of poetic signification. I hope to show, in juxtaposing aspects of Freud's systematic analysis of dreamwork with Du Bellay's text, that the latter deploys poetic and allegorical procedures that are strikingly close to Freudian dream analysis avant la 
lettre. Also of significance in this connection is the fact that both Du Bellay and Freud, with regard to the associational relations they are seeking to discover, inscribe their work in a tradition articulated by Artemidorus of Daldis. ${ }^{11}$

\section{Words in transit}

Of course, attempts to elicit meaning from the Songe refer to some of the sequence's principal intertexts, namely Petrarch's Canzone 323 (through Clément Marot's translation, "Des Visions de Pétrarque"), ${ }^{12}$ the Book of Ecclesiastes, the Book of Revelation, and the thirty-two foregoing sonnets of the Antiquitez. ${ }^{13}$ Although one could look to the meanings of the intertexts of the Songe to attempt to fix the meaning of the signs Du Bellay appropriates from them, such an interpretive gesture would overlook the transformation, often quite radical, that these intertexts usually undergo in their transference to his own text. Indeed, any attempt to link the signs of Du Bellay's Songe in a sequence must take into account the fact that the meaning of these signs emerges through a linking to other signs in their initial and new contexts. I would like to propose that the allegory of Du Bellay is one that valorizes the distance between one sign and another - that the "other story" of the Songe may concern precisely this distance, hence the limitations in the signifying capacities of poetic signs when placed in a particular context. Intertextuality is essential to the understanding of Du Bellay's poetry, and especially in the case of the Songe, intertexts must be seen as material to be drawn on to be completely reworked for the current, local context - and as bearing a close relationship to dream material. ${ }^{14}$

I make this suggestion in light of the relationship of words to their meaning delineated in the Antiquitez. Immediately preceding the Songe in the combined narrative of the two sequences, the Antiquitez end just before the dream begins - as the opening verses of Songe 1 tell us:

C'estoit alors que le present des Dieux

Plus doulcement s'écoule aux yeux de l'homme,

Faisant noyer dedans l'oubly du somme

Tout le soucy du jour laborieux. ${ }^{15}$

The more literal representations of Rome in the Antiquitez are the intertexts closest in space and narrative temporality to the Songe. If, in the narrative of the poet who is at work here ${ }^{16}$ the "soucy du jour laborieux" is an effect of the task of searching undertaken in the Antiquitez, then the beginning of the Songe appears to offer a sweet relief from the uncertainty involved in chanting "L'antique honneur du peuple à longue robbe" (Antiquitez 32, v. 14). Of course, as Du Bellay will show, this relief is only momentary. 
The problem that Du Bellay stages in the Antiquitez is that of the poet searching for a way to ground his words such that their meanings will be firm and fixed; to do this, the poet looks to the eternal city. With regard to a number of Latin poems, both ancient and contemporary, Du Bellay is putting in practice the notion of imitation that he delineated in the Deffence et Illustration de la Langue Francoyse. This practice involves borrowing pieces of text, moving them around, reordering them, and transforming them, so as to produce a new text that addresses and contributes to the current context; it is this procedure that the dream of the Songe continues. In the Antiquitez, Du Bellay expands the notion of imitation to integrate the antiquités or ruins of Rome themselves as mobile signs, continuing to move away in time from the glory of ancient Rome. ${ }^{17}$ Thus, in the very act of imitating the glories of the ancient city, both its monuments and the writings on them from antiquity and the present, the discovery is made that the city is not eternal. The ruins of Rome, then, are signs dislocated from their meaning: they do not represent, as may have been intended on their first construction, the eternal quality of the city, but rather the impossibility of eternity on earth. They have decayed specifically as signs: they do not signify their original meaning or their original state.

As is suggested by the full title of the sequences, Les Antiquitez de Rome contenant une generale description de sa grandeur, et comme une deploration de sa ruine, the primary mode of the Antiquitez is lamentation. But there is also an ironic dimension, in which the dislocation of signs from their meanings is valorized so that the poet becomes free to rework signs in a way that is specifically pertinent to the local, contemporary context - hence, to imitate. Imitation becomes precisely the freeing of signs from their original context and meaning so that they may be used to make entirely new works. In the Antiquitez, then, words are not at all fixed to their meanings, and this state of things is to the poet's advantage. The Songe, immediately following the Antiquitez, takes the latter as a series of signs to be reworked, treating them as dream material. In dreams, Freud tells us, words are often treated as though they were objects. ${ }^{18}$ Du Bellay's use of signs to construct poetic edifices and his treatment of the physical ruins of Rome as signs suggest that he has made a similar discovery. And it is certainly true that since biblical times, in the Western tradition, the dream has been regarded as a primary producer of allegory. Of course, the Songe is the recounting of a dream rather than a dream itself, and it almost certainly does not represent an actual dream. ${ }^{19}$ But its construction and productions of meaning still involve dream-work, as the recounting of a dream always does. ${ }^{20}$ 


\section{The names of the poet}

Although the images of the Songe continue the pagan references that mark the Antiquitez, we read in the first sonnet a sudden, because apparently unprecedented, invocation of Christian terms in answer to uncertainties raised in the Antiquitez. The suddenness is all the more marked because of the way in which the poet is brought out of the relief of first sleep into the dream world of Rome, which has contemporary, ancient, and biblical aspects to it. The poet had just fallen asleep,

Quand un Demon apparut à mes yeux

Dessus le bord du grand fleuve de Rome,

Qui m'appelant du nom dont je me nomme,

Me commanda regarder vers les cieux. (vv. 5-8)

This demon is most likely the "demon romain" of Antiquitez 27 (v. 12), hence, according to Thomas Zamparelli, "a supernatural being who often served as a mediator between man and the gods." ${ }^{21}$ At the outset of this dream and its recounting, the demon provides an interpretation, to which I will return. Du Bellay here takes elements of ancient texts to construct the dream: thus it is evident that the series of poems, as with the Antiquitez and in keeping with the notion of imitation, is made up of reworked material, words taken from another context and placed in this new situation.

The demon calls the poet "du nom dont je me nomme." Through the anagrammatical series of demon, du nom, and nomme, the poet is likening his own naming capacity to that of the demon, hence giving himself a quasi-divine role in the interpretation of his own dream. Moreover, the use of the word nomme as a rhyme with Rome recalls Antiquitez 3: in that sonnet, the rhyming pair underscores the difficulty of placing the name Rome on the ruins the poet sees before him, and thereby valorizes the mobility of the name in its lack of fixity to the thing it supposedly signifies, but from which it has been distanced through time. It is the work of the poet to move and relocate names, and here the poet suggests that his own unmentioned name has the same capacities. "Je me nomme" is ostensibly a passive verbal construction, but if it is taken rather as a reflexive, then the power of the poet to assign himself a name, and hence to produce his own textual persona from disparate elements, is emphasized. But the limitations to this power are also underscored: whether the construction is taken as passive or reflexive, the poet never gives his name, never names himself. The poetic construction of the poet, like the monuments of ancient Rome, remains tenuous.

That the demon directs the gaze of this poetically effected poet, his "vision" - in repetition of the title, further repeated in the many repetitions of and variations on the phrase "je vy" throughout the sequence ${ }^{22}$ - 
compounds the effect that Michael J. Giordano examined in his 1986 article, "Du Bellay's Songe and the Ambiguity of Narrative Authority." This aspect of the Songe is in keeping with its allegorical functioning, which invites the reader effectively to rewrite the poem: the reader in a way takes the place of the author, who relinquishes strict control over meaning. ${ }^{23}$ As the poet has no fixed name, the "je" of the narrator may signify in multiple fashion. Du Bellay thereby invites his addressees to continue the procedure that he has initiated with the Antiquite $z$ and the Songe in relation to prior texts, to take pieces of these texts and place them in a new context, so that a current meaning may be produced. Readers are in effect asked to surpass Du Bellay's series of poems, as Du Bellay is surpassing the poetry of antiquity in his own writing - and allegorizing this surpassing.

The demon serves as guide, then, not only to the narrating poet but also to a would-be decipherer of the Songe. His role as interpreter is thus quite pronounced, and in relation to the recounted dream it prefigures the role of psychoanalyst. His close relationship with the poet suggests the central role the analyst gives the patient in the interpretation of dreams. Riffaterre astutely points out that the lesson of the Songe is not hidden, as many critics have assumed, but rather given in so many words by the demon in the first tercet, in an echo, repetition, or imitation of a key phrase from the Book of Ecclesiastes: 24

Puis m'escria, Voy (dit-il) \& contemple

Tout ce qui est compris sous ce grand temple,

Voy comme tout n'est rien que vanité.

To borrow from the vocabulary of psychoanalysis, there is a condensation of pagan and Christian terms in the demon's apparently sudden use of the biblical phrase. I say apparently because this allusion to the Bible opens another possibility of interpretation with regard to Rome: some phrases also borrow from biblical passages in a condensation that produces a meaning that does not derive directly from either source, but that is rather effected in the new context. Such condensation, an aspect of dream-work, ${ }^{25}$ is essential to the allegorical sense of the Songe.

\section{Biblical dreaming}

The two books of the Bible most operative in the Songe, Ecclesiastes and Revelation, work together in a dreamlike condensation of Old and New Testament. The aspects drawn from each in the Songe set the two at odds with each other, especially on the conception of time. The cyclical time of Ecclesiastes - "Toutes choses ont leur saison" (3:1), "Temps de naistre, \& 
temps de mourir" (3:2), and so on - does not work well in conjunction with the teleological time of Revelation. The violence of the imagery in the Songe is in part a result of the blend of these two conceptions of time. In sonnet 14, the poet speaks of seeing "une Cité quasi semblable à celle/Que vit le messager de la bonne nouvelle" (v. 3), an evident allusion to Revelation 21:2. This dream version of Rome is the poet's new Jerusalem, where the wish for the perfection of poetry in French, as expressed in the Deffence, may be fulfilled. In his expression of that wish, which in the Deffence begins on an apocalyptic note, Du Bellay projects a future for French poetry that Floyd Gray has termed a "utopie linguistique."26 "Le tens viendra," he writes, echoing the apocalyptic phrase "le temps est prés," when works in French will be regarded as models for poets to draw from, as the works of antiquity are for the French Renaissance poet. ${ }^{27}$ Du Bellay thus suggests that works in French may also move, over the course of time, into the past, as have the works of Rome. Of course, this poetic new Jerusalem is only "quasi semblable" to the city of Revelation - it is a likeness or image of it, and Du Bellay's poems in turn present a likeness or image.

In the Antiquitez, the discovery is that Rome is indeed a thing of the past, a pile of crumbling ruins; the composition of the sonnet sequence in French indicates none other than the wish for the poetic new Jerusalem, or the resurrection of Rome in France. Hence, as Deborah Lesko Baker has keenly demonstrated in connection with the Antiquitez, Du Bellay's sonnet sequences are marked by a dual conception of time that involves a "double eternity": the first is "a richly mythic framework . . . a privileged eternal realm capable of transcending historical reality," 28 which would be represented in the idea of an eternal Rome; the second is an eternity of time itself, which consumes "all human things." ${ }^{29}$ In the Songe, then, one wish-fulfillment concerns the creation of a poetic new Jerusalem in contemporary, French-occupied Rome, and by extension in France itself - the idea of an eternity transcending time. That the wish is immediately dashed by the consuming powers of time involves the second component of the wish-fulfillment, to which I will return below.

The poet's discovery of the lack of durability of all things extends even to the notion of the linguistic utopia, the poetic new Jerusalem, or the resurrected Rome. The demon periphrastically describes the world - the Rome that, in the dream-world, extends over the entire world ("Rome fut tout le monde, et tout le monde est Rome" [Antiquitez 26, v. 9]) — as "Tout ce qui est compris sous ce grand temple." The allusion to Revelation is evident: "Et ne vei point de temple en elle: car le Seigneur tout-puissant est le temple d'icelle, de l'Agneau" (21:22). ${ }^{30}$ Whereas in Revelation the world is a temple precisely because God is present and eternity has arrived on earth, 
in the Songe the temple-world is temporal and presents only a simulacrum of eternity, God remaining unreachable by human effort. And even at the very end of the Antiquitez, there is a similar response to the Apocalypse: the only hope for overcoming the corrosive effects of time is in this verse, which has represented "L'antique honneur du peuple à longue robbe" (32, v. 14). The description of the Romans alludes to Revelation, in which those who have entered the new Jerusalem and are with God wear "longues robbes" (7:13-14). ${ }^{31}$ The expression involves an additional condensation, an allusion to Virgil's "gentem . . . togatem" 32 - the Romans, inhabitants of the eternal city that, to the poet's express chagrin, has passed away into dust.

It is likely, then, that any immortality or eternity that the poet might effect can be nothing but vanity or simulacrum. I understand the term simulacrum in the following sense, derived from Platonism: a decayed image, the image of an image, and not an image that participates in the eternal form or eidos (Plato, Republic, 596a-597b). In Du Bellay's problematic, Rome is sought as that which participates in eternity or perhaps even embodies it. The discovery is then made that Rome was not the eternal city, and so its ruins and the poetry about them can constitute no more than a decayed image or poor copy. However, what I am trying to underscore in Du Bellay is a reconception of the simulacrum such that, in the discovery of the nonexistence of any accessible divine or eternal original, the simulacrum may become an affirmation rather than a mere privation. That is, even though it begins with Rome and Roman poetry as models, by presenting itself as one in a series of simulacra, Du Bellay's poetry may call into question the legitimacy and fixity of those models and hence assume an autonomy for itself. Du Bellay is implicitly taking issue with the Platonic notion of the simulacrum, exemplified in poetry and banished from the Republic because of its capacity to seduce and deceive (Republic, 606e-607c). My interest here is not so much to signal Du Bellay's particular relationship to Platonic doctrine; 33 it is, rather, to explore his criticism of what has been characterized as a governing distinction in the history of Western thought, that between simulacrum and true image, definitively articulated in the Platonic texts. ${ }^{34} \mathrm{Du}$ Bellay valorizes poetry and the complexities of its simulating capacities in the process of debunking the notion that there is a unique, eternal form or idea of patria embodied in Rome. The poet, as the manipulator of language and its imagery, may hence relocate the patria to contemporary France - only to leave it free to move on again, with the passage of time. 


\section{A time of poetic words}

In the final tercet of Songe 1, the question of time is raised, in dialogue and continuity with the same question in Antiquitez 3. In keeping with Du Bellay's procedure, Songe 1 reworks verses from Antiquitez 3, and a new meaning is produced. The latter laments the "mondaine inconstance" (v. 12) of the contrast between the Tiber, the one piece of ancient Rome that remains intact in modernity, and the rest of the city, which has fallen into ruin. The Tiber remains because of its flow, which bears a similarity to, and even converges with, the flow of time. It is time, endowed with the erosive power of flowing water, that has destroyed the once-solid and apparently eternal city: "Ce qui est ferme, est par le temps destruit / Et ce qui fuit, au temps fait resistence" (vv. 13-14). Songe 1 replies to the despair of being unable to lay hold of anything solid or even real in this world, as Du Bellay's narrating poet hoped to do in traveling to Rome. Now, the "mondaine inconstance," repeated in this poem, is the fleeting quality of everything. The object of the poet's quest becomes transformed as follows: "Puis que Dieu seul au temps fait resistence / N'espere rien qu'en la divinité" (vv. 13-14). George Hugo Tucker advances the interpretation that Songe 1 is a "biblical reply ... to the pagan questioning" of Antiquitez 32,35 in which the poet wonders if eternity may be hoped for in his verses: the demon replies to him that hope is to be placed only in God, who alone withstands the erosion of time.

I propose to amend this interpretation. First, I would like to emphasize that the pagan questioning of Antiquitez 32 borrows an element from the Book of Revelation in order to suggest that any version of immortality or eternity on earth can be only a simulacrum. The eternal realm remains infinitely distant from finite life on earth; the latter cannot participate in the former, can produce no adequate image of it. Secondly, I would like to suggest that, whereas the assumption of this interpretation is that Du Bellay accepts the notion of Christian divinity as a grounding force, his fascination with the pagan world in the Antiquitez and the Songe, which extends to the production of an allegory not easily assimilable to Christian decipherment, and which indeed seriously questions apocalyptic time, might indicate otherwise. Arguably, "Dieu" is mentioned in Songe 1 not to oppose "ce qui fuit" but rather to repeat it: God becomes something that flees from the world, or even the very essence of this flight, in that no fleeting image in the world may be firmly grounded. According to Ecclesiastes, "Vanité tresvaine, tout est vanité" (1:2). All that is available to human beings on earth is a series of fleeting images, a simulacrum of permanence; divine purpose, belonging to the realm of eternity, is not accessible to human knowledge. 
In the Antiquitez, it is Rome that is sought in order to fix meaning, and Rome that cannot offer such fixing; in the Songe, even God cannot or will not do so. Rather, the poet must learn to live with and in what is fleeting: the texts from which he or she borrows must be accepted as transmutable, ${ }^{36}$ and the words he or she recasts in the form of new works must be seen as continuing the same movement. The latter is not in the power of the poet, or anyone or anything else in existence, to check. Hence, as Du Bellay declares in the Deffence, works in French may in the future be taken as models to be imitated and recast, as the models of antiquity are for the poet of the Renaissance. In this poetic production, the poet hopes that the ancient models will be surpassed by his or her own poetry in French. These models will, in this poetic movement of history, pass away as have the "pouldreuses ruines" (Antiquitez 27, v. 14) from which Du Bellay's sonnets were initially created: "tout est de poudre, $\&$ tout retourne en poudre" (Ecclesiaste 3:20). In that future time when French poetry may offer models, it will already be haunted by the dusty ruins on which it is built, and may well be on the way to the status of antiquity through being imitated - in other words, to a return to dust.

The hope that the demon tells the poet to have in divinity thereby amounts to a faith in the continuation of the flow, mobility, and transmutability of poetic language. Hence, the close relationship of the poet with the demon, as mediator between divine and human realms, is pushed further. It is essential to take note, in the demon's speech, of the transformation of the borrowed biblical text: instead of "tout est vanité," we read "tout n'est rien que vanité." 37 A negation is added: rien stands in glaring antithesis to the word tout, so that the latter word's emptiness of meaning or vanity is underscored. Vanité thereby comes to signify, not only emptiness, but also the fluid relation of a word to its meaning: in the flow of time, no word is fixed to its meaning, and may indeed become an image of meaning that is not meaning, a simulacrum. The juxtaposition recalls Du Bellay's placement of the name "Rome" in sonnet 3 of the Antiquitez: "Nouveau venu qui cherches Rome en Rome, / Et rien de Rome en Rome n'apperçois" (vv. 1-2). The repetition demonstrates that, as a function of the continuity of the poem, the name is emptied of meaning - that rien, phonetically and anagrammatically resonating with Rome, is what is left of the meaning of the word. Rome has become vanité, as has its name. ${ }^{38}$ As the one eternal thing on earth, or so the poet wishes, "Rome" was to be the anchor of meaning for all words. If poetic words could have participated in this eternal thing, they could have offered an image of eternity. But Rome/"Rome" has failed, and all words can be nothing but simulacra. The Songe itself, as a dream, is also a simulacrum, a transformation of words and images from prior texts into words and images that have no existing original referent — as the many 
attempts to decipher the imagery of the Songe usually end up showing. Indeed, Ecclesiastes itself makes the connection among songe, vanité, and a proliferation of words: "Car où il y ha plusieurs songes, il y ha moult de vanité \& de paroles" (5:6).

Yet, again as a dream, the Songe is simultaneously wish-fulfillment. Throughout The Interpretation of Dreams, Freud continually affirms that every dream functions as such; Du Bellay seems to have made a similar discovery. The principle applies to the Antiquitez, as I have already suggested, and the wishes therein expressed are recast in dream form in the Songe. In fact, the Antiquitez express two contradictory wishes: one is that Rome were the eternal city that would ground the meaning of the poet's words, the poet's New Jerusalem; the other is that Rome were in fact ruined, belonging to the past, a vanity and a demonstration of earthly vanity, a simulacrum. With Rome in ruins, space is made for the grandeur of French poetry - for the erection of the poetic new Jerusalem, a Rome made of French words, in French-speaking territory. The Solomonic cycle of creation and destruction continues. The work of poetry, borrowing from dream-work, displaces the wish for a French poetic utopia onto Rome. ${ }^{39}$ Rome is essential to any conception of temporal and historical change in Renaissance Europe. ${ }^{40}$ But the wish for Rome's destruction becomes an anxiety concerning the inevitable destruction of the greatness of French poetry by the same temporal motion that has made its construction possible in the first place.

\section{Wishes for Rome}

In Antiquitez 9, Du Bellay goes so far as to propose that Rome's failure to be durable is proof of the impossibility of any durability, even in the divine realm: "ce grand Tout doit quelquefois perir" (v. 14). If the second wish were to come true, then the poet could take what he would from Rome, its ruins, and its writings, which would now be freed from their initial context in order to create the poetry in French that would offer models to posterity. Such an act would be a thoroughly humanist contribution to the historical movement of translatio studii, the transfer or translation of ancient and developing learning from predecessor to successor in the general direction of Western expansion. ${ }^{41}$ Du Bellay could thereby declare the glory of the French state, the new empire that may rival and surpass Rome in the movement of history (this wish is, of course, explicitly stated in the Deffence). This empire may also surpass Renaissance Italy, both militarily and poetically: Du Bellay works toward transposing the Petrarchan sonnet into a French form. (In 
doing so, he also borrows from Petrarch's "Vision," whose movement of creation and destruction he imitates in the Songe. ${ }^{42}$ )

If we understand the Songe as a dream involving two contradictory wishes, it is easy to see why, in each poem, something very beautiful, admirable, or awe-inspiring is described, which at the end falls into complete ruin. Exemplary of the fragility of the monuments described in the Songe is the opening quatrain of sonnet 14 :

Ayant tant de malheurs gemy profondement, Je vis une Cité quasi semblable à celle Que vit le messager de la bonne nouvelle, Mais basty sur le sable estoit son fondement. (vv. 1-4)

These lines offer a reworking of the general strategy of the Antiquitez, which is to emphasize the emptiness of Rome's monuments by not describing them at all. Here, in dual wish-fulfillment, the dream produces full and clear images of an eternal city that cannot be eternal because its foundation is built on sand - an allusion to the Gospel of Matthew. ${ }^{43}$ Also signaled here, of course, is Saint John the Divine, whom Du Bellay identifies, according to the convention of his time, with Saint John the Apostle, "le messager de la bonne nouvelle." Nietzsche has read the Book of Revelation as an extreme expression of wish-fulfillment, a revenge fantasy on the part of the oppressed; he even signals the irony involved in "the profound consistency of Christian instinct," which "inscrib[es] this book of hate to the disciple of love." 44 Saint John witnesses the destruction of Rome, personified as the Whore of Babylon: "Et je vei la femme enyuree du sang des saints, et du sang des martyrs de JESUS" (Apocalypse 17:6). In this dream-vision, the place where Christians have been viciously persecuted will be destroyed; Jerusalem will be built anew, where Christians may live through eternity.

In his dream version of Rome, Du Bellay reworks the New Jerusalem of the Book of Revelation, effectively transforming a revenge fantasy into a hope for a continuation of poetry in the repetitions of cyclical time. When he enters the holy city, John describes what he sees in detail, and the architecture is splendid, dazzling, made of the finest, most precious, shiniest materials (Revelation 21). Although M. A. Screech remarks that the details of Du Bellay's descriptions of buildings in the Songe "correspondent à une signification plus ou moins ésotérique," destined to obscurity, ${ }^{45}$ Du Bellay's pattern of offering details, as well as some of the details themselves, strongly recalls Saint John. For example, guided by an angel that Gadoffre has likened to the demon of the Songe, 46 John sees Jerusalem from a "montaigne," provides its shape and dimensions, and compares the light from the city to a precious stone, like "jaspe," as clear as "crystal" (21:11). The "muraille" 
of the city is built from "or pur" (21:18), and its foundations from precious stone: "jaspe" and "esmeraude" (21:19), among others. ${ }^{47}$ Similarly, in sonnet 2, the poet sees "sur la croppe d'un mont" (v. 1) an enormous building, "une Fabrique/De cent brasses de hault" (vv. 1-2), whose "muraille" is made "d'un luisant crystal"; integral to its construction is "or" (vv. 8-10), and it is decorated with "jaspe" and "esmeraulde" (v. 11). Just as the monuments in the poem are built of materials described in Revelation, the poem is constructed of words that compose the descriptions in the latter (to say nothing, for the moment, of other borrowings).

It is quite evident that Du Bellay is imitating Revelation in order to build his poetic new Jerusalem; this Rome is oneirically resurrected, so that the poet may reach the realm of the eternal, firmly ground the meaning of his words, and achieve immortality through the supposed immortality of Rome. But the cyclical time of Ecclesiastes, merging with the movement of Petrarch's "Vision," inserts itself in the final tercet:

O vanité du monde! un soudain tremblement

Faisant crouler du mont la plus basse racine,

Renversa ce beau lieu depuis le fondement. (vv. 12-14)

This new Jerusalem not only lacks firm grounding but is also susceptible of being utterly destroyed, with the cataclysmic suddenness that marks Revelation. The destroyed city also borrows elements from Rome, both ancient and contemporary: Gadoffre points out that the description of the "Poincte aiguisee" of sonnet 3 refers to the obelisk of the Vatican, the urn on top of which supposedly holds "D'un grand Caesar la cendre composee" (v. 8). ${ }^{48}$ Du Bellay here takes the wish of Revelation for the destruction of Rome and the resurrection of Jerusalem as an eternal city, and through a transmutation divides this wish into two wishes: one is for the resurrection of Rome as an eternal city (a new Jerusalem for the Renaissance poet), and the other is for its destruction, the affirmation of its vanity. But this vanity is precisely what allows the poet to take portions of Roman writing through imitation and produce his own writing, which subsequently enters the stream of time and becomes subject to the transformation that Roman writing has undergone. The poet cannot bring back ancient Rome; writing about it as Du Bellay does in the Antiquitez and the Songe affirms both the efficacy and the inefficacy of present-day poetry.

Contradictory wish-fulfillment, according to Freud, occurs when an unconscious wish is countered by a wish from the preconscious, as a defense for consciousness, to which the first wish is unacceptable. ${ }^{49}$ When this operation occurs in a dream and the unconscious wish persists against the defense, an anxiety dream occurs; the only defense remaining to the precon- 
scious is to arouse the dreamer. ${ }^{50}$ Throughout the Songe, each time a beautiful monument is described, one senses the wish for a recovery of ancient Rome, for the eternal city that Du Bellay's poetry reveals to be a simulacrum. At the same time, one senses the destruction of each monument as part of the defense against the durability of Rome enacted by the French new poetry, the poetic New Jerusalem, the modern incarnation of Rome in France. In turn, the defense against the durability of this poetry is a kind of death-wish, a desire to join Rome in the movement of time, to move into the past. And this is paradoxically a wish for new life, as it will give way to whatever poetry might follow the French monuments. Apocalyptic time is caught up and undone in the movement of cyclical time.

In sonnet 15, Rome is destroyed, in the allegorical figure of "la soeur du grand Typhee" (v. 4), ${ }^{51}$ who "En majesté sembloit egale aux Dieux," to the distress of the dreaming poet:

Le ciel encor je luy voy guerroyer,

Puis tout à coup je la voy fouldroyer,

Et du grand bruit en sursault je m'esveille. (vv. 12-14)

Du Bellay effects a condensation of the lightning bolts of Greco-Roman mythology and the spectacular destruction of Babylon or Rome in Revelation 16. It is worth noting that well before Freud, an arousal dream was considered to be the index of a serious disturbance that might bode ill. ${ }^{52}$ The dual wish-fulfillment function of the Songe is indicative of such a disturbance and may well be read as an ill omen for the future of poetry in French.

\section{A future of poetry}

In the language of the dream he represents, Du Bellay borrows extensively from prior texts to produce his series of poems, a procedure allegorized in the creation of monuments in the dream version of Rome. This very procedure, while affirming the greatness of ancient Rome, must also affirm its ruin and death, so that its poetry may be reworked into models in French for the future. According to the Deffence, French is the great poetic language of the future, the dream language. And according to Christian apocalyptic narrative, Rome must be destroyed to make way for the new Jerusalem. It is not at all clear from his Roman sonnets that Du Bellay accepts this narrative, in which eternity will finally arrive at the end of earthly time. Rather, the wish-fulfillment may also involve an opposition to contemporary Rome, to the Roman Catholic Church, which Du Bellay was hardly in a position to state explicitly. ${ }^{53}$ In Antiquitez 17, with the phrase "la corneille Germaine" (v. 9) he characterizes the Holy Roman Empire as the usurping simulacrum 
of ancient Rome, which he answers with his own poetry as the simulacrum in which Rome will be repeated and imitated for the benefit of French poetry ${ }^{54}$ However, in this imitation of Roman poetry, which is of necessity a simulacrum, a vanity that cannot reach immortality, the affirmation is also at least implicit that the same fate may well befall France, the French language, and French poetry; hence the Songe constitutes, in its multiple significations, a bad omen. Built on the sand of ancient Rome, French poetry, if it is to offer models to another era, another language, another poetry, may also fall into ruin. The Songe substitutes for the Christian apocalyptic vision a cyclical time borrowed from both ancient mythology and the Ancien Testament. The divinity in which the poet is told to hope is none other than the continuity of poetry, which must periodically fall into ruin only to be resurrected as something entirely different in the next era of doomed greatness. Such a poetry is Du Bellay's dream.

\section{University of Connecticut}

\section{Notes}

1. Cf. M. A. Screech, in Joachim Du Bellay, Les Regrets et autres œuvres poëtiques: suivis des Antiquitez de Rome, plus un Songe ou Vision sur le mesme subject, textual ed. J. Joliffe, introd. and commentary by M. A. Screech, 2nd ed., Textes littéraires français 120 (Geneva: Droz, 1974): "Dans le Songe, Du Bellay ne nous semble pas toujours éviter un obscurantisme facile” (p. 35). Gilbert Gadoffre, in Du Bellay et le sacré (Paris: Gallimard, 1978), terms the Songe "un des textes poétiques les plus obscurs du répertoire français." He adds, "C'est une obscurité voulue" (p. 151).

2. Cf., e.g., Michael J. Giordano, "Du Bellay's Songe and the Ambiguity of Narrative Authority," Oeuvres et Critiques 11.1 (1986): 61; Sharlene May Poliner, "Du Bellay's Songe: Strategies of Deceit, Poetics of Vision," Bibliothèque d'Humanisme et Renaissance 43 (1981): 509; and Thomas L. Zamparelli, "Du Bellay’s Songe Re-examined," Forum for Modern Language Studies 28 (1992): 209.

3. E.g., George Hugo Tucker, The Poet's Odyssey: Joachim Du Bellay and the Antiquitez de Rome (Oxford: Oxford University Press, 1990).

4. As recently as 1971, L. Clark Keating writes: "There are among us few readers interested in enigmas in poetic form. Perhaps in his own day, when puzzles and acrostics were a favorite parlor game, the reception of these sonnets may have been more favorable than it is today" (Joachim Du Bellay [New York: Twayne Publishers, 1971], p. 96; quoted in Zamparelli, p. 209).

5. I am invoking a simple definition of allegory here, that deriving from its etymology.

6. Poliner, p. 515.

7. Gadoffre, pp. 151-82.

8. Michael Riffaterre, “Intertextual Semiosis: Du Bellay's `Songe,' VII,' in Text Production, trans. Terese Lyons (New York: Columbia University Press, 1983), pp. 111-24.

9. Ibid., p. 111. 
10. Jacques Lacan, "L'instance de la lettre dans l'inconscient, ou la raison depuis Freud," in Ecrits I (Paris: Seuil, 1966): "La première clause articulée dès le chapitre liminaire [de l'Interprétation des rêves], parce que l'exposé n'en peut souffrir le retard, c'est que le rêve est un rébus. Et Freud de stipuler qu'il faut l'entendre comme j'ai dit d'abord, à la lettre. Ce qui tient à l'instance dans le rêve de cette même structure littérante (autrement dit phonématique) où s'articule et s'analyse le signifiant dans le discours. Telles les figures hors nature du bateau sur le toit ou de l'homme à tête de virgule expressément évoquées par Freud, les images du rêve ne sont à retenir que pour leur valeur de signifiant, c'est-à-dire pour ce qu'elles permettent d'épeler du 'proverbe' proposé par le rébus du rêve. Cette structure de langage qui rend possible l'opération de la lecture, est au principe de la signifiance du rêve, de la Traumdeutung" (p. 268).

11. In the Deffence et Illustration de la Langue Francoyse (1549), Du Bellay justifies his advocacy of the use of anagrams in poetry by referring to Artemidorus: "Artemidore aussi le Stoïque a laissé en son livre des Songes un chapitre de l'anagrammatisme, ou il montre que par l'inversion des lettres on peut exposer les songes" (ed. Henri Chamard [Paris: Didier, 1948], p. 155). In his Oneirocritica (written in the second century C.E.), Artemidorus devotes a great deal of space to the interpretation of letters and words in dreams, and states specifically: "One must also show some degree of independent skill in judging dreams which are mutilated and which do not, as it were, give one anything to hold on to, especially [in the case of very difficult ones] in which certain letters which do not contain a thought that is whole and entire in itself or a meaningless name are seen, sometimes by transposing, sometimes by changing, sometimes by adding letters and syllables to them, sometimes by inventing others that are of equal numerical value, so as to make the meaning clearer" (The Interpretation of Dreams [Oneirocritica], trans. Robert J. White [Park Ridge, NJ: Noyes Press, 1975], book 1, chapter 11, 22).

Freud borrows from Artemidorus more than the title of his great work on the discovery of the letter of unconscious association. In a footnote to the 1914 edition of The Interpretation of Dreams, he goes so far as to credit the latter with "the most complete and painstaking study of dream-interpretation as practised in the Graeco-Roman world" (The Interpretation of Dreams, trans. James Strachey, corrected ed., 2 vols. [London: Hogarth Press, 1958], p. 98, n. 1) — that is, he identifies Artemidorus as a precursor with regard to his own scientific method. Freud continues: "He insisted on the importance of basing the interpretation of dreams on observation and experience, and made a rigid distinction between his own art and others that were illusory... . A thing in a dream means what it recalls to the mind - to the dream-interpreter's mind, it need hardly be said. . . . The technique which I describe differs in one essential respect from the ancient method: it imposes the task of interpretation on the dreamer himself. It is not concerned with what occurs to the interpreter in connection with a particular element of the dream, but with what occurs to the dreamer."

12. Francesco Petrarca, Canzoniere, ed. Ugo Dotti, 2 vols. (Rome: Donzelli, 1996), 2: 842-48; Clément Marot, Euvres, 4 vols. (Paris: Delarue, 1876), 3: 183-85.

13. It is important to note that the two Biblical texts were also available to Du Bellay in the Huguenot translation of the Bible, a later version of which would include Marot's and Théodore de Bèze's verse translations of the Psalms, and that Du Bellay takes up and continues the Reformist gesture by deliberately borrowing Biblical phrasing and placing it in a contemporary and local context. I will show that in one important instance Du Bellay's wording of biblical allusion shows a closer affinity to the Geneva Bible than to the 1550 Catholic translation of Louvain, the only one permitted in French by Charles Quint. I do not want to foreclose on the possibility of Du Bellay's Gallicanism, as Gadoffre's reading of the Songe is quite compelling. 
But I would like to suggest a syncretism in Du Bellay's work, which may be more common in writers of the French Renaissance than one usually imagines. In this respect, I am less interested in available biographical details on Du Bellay's religious affiliations than in the signifying effects of his writing. As it is close in a number of ways to Du Bellay's poetic/spiritual project, I will cite primarily the following edition of the Bible: La Bible qui est toute la Saincte escriture du vieil et du nouveau Testament (Lyon: Jan de Tournes, 1561); BNF digitized version, N053622. This edition is based on Calvin's 1546 revision, with the addition of numbered verses from the 1553 edition by Robert Estienne. $C f$. Frédéric Delforge, La Bible en France et dans la francophonie: Histoire, traduction, diffusion (Paris: Publisud, 1991), pp. 75-87.

14. Cf. Sigmund Freud, "The Material of Dreams - Memory in Dreams," in The Interpretation of Dreams, pp. 11-21.

15. Joachim Du Bellay, Songe, in Les Regrets et autres oeuvres poëtiques, p. 269. All subsequent references to the Songe and the Antiquitez will be to this edition; particular sonnets will be designated by number in the body of the text.

16. The poet implicated in the Antiquitez and the Songe, the speaker who is ostensibly writing the verses, is not strictly identical to Du Bellay; rather, his experiences and attitudes often fictionalize those of Du Bellay. Throughout, I will maintain a terminological distinction between the two.

17. I am here summarizing my account of imitation, as it is advanced and carried out in both the Deffence and the Antiquitez: see Hassan Melehy, "Du Bellay and the Space of Early Modern Culture," Neophilologus 84 (2000): 501-15, and "Du Bellay's Time in Rome: The Antiquitez," French Forum 26.2 (Spring 2001): 1-22. My reading of the Antiquitez and understanding of imitation are indebted to the work of many commentators; see esp. Floyd Gray, La Poétique de Du Bellay (Paris: Nizet, 1978), p. 46; Deborah Lesko Baker, "Du Bellay's Double Eternity: Two Sonnets from the Antiquitez de Rome," Neophilologus 73 (1989): 354; and Barbara Bowen, The Age of Bluff: Paradox and Ambiguity in Rabelais and Montaigne (Urbana: University of Illinois Press, 1972), pp. 17-20.

18. "The linguistic tricks performed by children, who sometimes actually treat words as though they were objects and moreover invent new language and artificial syntactic forms, are the common source for these things in dreams and psychoneuroses alike" (Freud, p. 303).

19. Cf. Fernand Hallyn, "Le Songe de Du Bellay: de l'onirique à l'ironique," in Du Bellay: Actes du Colloque International d'Angers du 26 au 29 Mai 1989 (Angers: Presses Universitaires d'Angers, 1989), p. 305.

20. $C f$. Freud, pp. 512-32.

21. Zamparelli, p. 214. Cf. also Giordano: "In and of itself the word démon has a weighty lexical history. The poem's context, however, suggests its Greek meanings. In Plato, the demon is the intermediary between the gods and men, or the guiding genius that attracts us to our divine origins" (p. 63).

22. Cf. Zamparelli, p. 210.

23. Cf. Giordano, pp. 61-62, 66, and 68.

24. Riffaterre, pp. 111-12.

25. See Freud, pp. 279-304.

26. Gray, p. 20.

27. "Le tens viendra (peut estre), \& je l'espere moyennant la bonne destinée Francoyse, que ce noble et puyssant Royaume obtiendra à son tour les resnes de la monarchie, \& que nostre 
Langue (si avecques Francoys n'est du tout ensevelie la Langue Francoyse) qui commence encor' à jeter ses racines, sortira de terre, \& s'elevera en telle hauteur \& grosseur, qu'elle se poura egaler aux mesmes Grecz et Romains, produysant comme eux des Homeres, Demosthenes, Virgiles \& Cicerons, aussi bien que la France a quelquefois produit des Pericles, Nicies, Alcibiades, Themistocles, Cesars \& Scipions" (Du Bellay, Deffence, pp. 27-28).

28. Baker, p. 351.

29. Ibid., p. 355.

30. Exactly the same sentence appears in the Catholic Louvain Bible (La Saincte Bible nouvellement translatée de latin en françois [Louvain: Grave, Bergagne et Uvaen, 1550]; $\mathrm{BNF}$ digitized version, N053708).

31. The Louvain Bible gives the same expression.

32. Virgil, Aeneid, 1.282.

33. This topic has been thoroughly treated by Robert Valentine Merrill in The Platonism of Joachim du Bellay (1923; rpt. Chicago: University of Chicago Press, 1985).

34. Gilles Deleuze discusses the possibilities and implications of reconceiving the simulacrum in "Platon et le simulacre," in Logique du sens (Paris: Minuit, 1967), pp. 292-307. For an excellent commentary on the theoretical problem of the simulacrum in the perspective of contemporary literary theory, see Scott Durham, Phantom Communities: The Simulacrum and the Limits of Postmodernity (Stanford, CA: Stanford University Press, 1998), especially pp. 7-17.

35. Tucker, p. 183.

36. Cf. Du Bellay, Deffence: "Les anciens Romains ..., en guise de bons agriculteurs, l'ont premierement transmuée [leur langue] d'un lieu sauvage en un domestique" (p. 25, my emphasis).

37. Here is where it becomes significant that Du Bellay's wording of this very important phrase alludes to the Geneva Bible, not the Catholic Louvain translation, which renders this phrase as "touteschoses sont vanité." As the wording in the Vulgate is “omnia vanitas," Du Bellay's phrase strongly suggests an affinity with the Huguenot Bible.

38. Cf. especially Baker, p. 354.

39. Cf. Freud, "The Work of Displacement," in The Interpretation of Dreams, pp. 305-9.

40. $C f$. Edward Benson, "Du Bellay et la perception onirique de l'histoire: pour une lecture interprétative du Songe," Nouvelle revue du seizième siècle 4 (1986): 63: "Le prestige dont jouissait Rome dans toute l'Europe faisait un symbole significatif pour une vision de l'histoire."

41. See Ernst Robert Curtius, European Literature and the Latin Middle Ages, trans. Willard R. Trask (Princeton, NJ: Princeton University Press, 1953), p. 29.

42. See Hallyn, p. 308.

43. See Screech, p. 320, n. 4.

44. Friedrich Nietzsche, On the Genealogy of Morality, trans. Carol Diethe (Cambridge: Cambridge University Press, 1994), p. 35.

45. Screech, p. 308, n. 14.

46. Gadoffre, p. 146.

47. The names of the materials are the same in the Louvain Bible. 
Hassan Melehy / Joachim Du Bellay's Dream Language / 21

48. Gadoffre, pp. 160-61.

49. Freud, pp. 372-74.

50. Ibid., pp. 380-82.

51. Cf. V.-L. Saulnier, "Commentaires sur les Antiquitez de Rome," Bibliothèque d'Humanisme et Renaissance 12 (1950): 112-13.

52. See Screech, p. 322, n. 14. Screech remarks that during the Renaissance, the learned regarded an arousal dream as "de mauvais augure," but the passage from Rabelais that he quotes in support of his statement indicates a broader set of notions: "En fin vous esveiglastez en sursault fasché, perplex, et indigne. . . Sçaichez pour vray, que tout sommeil finissant en sursault, et laissant la peronne faschcée et indignée, ou mal signifie, ou mal praesagist" (François Rabelais, Le Tiers livre, in Oeuvres complètes, ed. Mireille Huchon [Paris: Gallimard, 1994], p. 395).

53. See Giordano, p. 74, and Gadoffre, pp. 181-82.

54. See Gadoffre, p. 99, and Melehy, "Du Bellay's Time in Rome," p. 17. 